\title{
Carers and breathlessness
}

Morag Farquhar RGN BSC (Hons) MSc PhD

University of East Anglia

School of Health Sciences, University of East Anglia, Norwich Research Park, Norwich, Norfolk, NR4 7TJ, UK

Telephone: 01603-597649

Email: M.Farquhar@uea.ac.uk 


\section{ABSTRACT}

\section{Purpose of the review:}

Informal carers play a key role in supporting patients living with breathlessness in advanced disease, but with considerable impacts on their own well-being. The purpose was to review recent advances in our understanding of the caring role in refractory breathlessness, its impacts on carers, and interventions to support them.

\section{Recent findings:}

A systematic literature search resulted in 28 included papers that could be mapped to four broad areas of carer enquiry: the carer role $(n=6)$, role impact $(n=7)$, carer support $(n=11)$, and carer views $(n=4)$. Search terms focused on breathlessness, but few of the included papers were exclusively on breathlessness: most were disease-related, predominantly COPD. There were a range of methodologies, including four systematic reviews; UK studies were most common.

\section{Summary:}

Carers of patients with breathlessness take on a role characterised by uncertainty, largely unsupported by health care professionals (HCPs). HCP acknowledgement of these carers, their contribution, and the impact of the caring role, is lacking. The patient-carer dyad should be considered the unit of care. Carer intervention should be individualised, supporting carers as clients and co-workers. There was a dearth of studies recruiting via primary care, focusing on conditions other than COPD, and longitudinal work.

\section{KEYWORDS}

Carers, breathlessness, COPD 


\section{INTRODUCTION}

Chronic breathlessness has wide-ranging, inter-related physical, psychological, social and existential consequences for both patients and family and friends supporting them [1] (informal carers). Carers play a key role in supportive, palliative and end of life care for patients with advanced respiratory conditions [2]. There is growing interest in their role in supporting patients with breathlessness (carers as co-workers [3]), and in the impacts of that role on carers themselves (carers as clients [3]) and ways to support them. A systematic search was therefore conducted to identify recent relevant literature: Box 1 summarises the search strategy.

[Box 1 about here]

\section{$\underline{\text { RESULTS }}$}

Twenty-eight papers were included [4-31]: Table 1 summarises their characteristics. Search terms focused on breathlessness, but few included papers were exclusively on breathlessness: most were disease-related, predominantly COPD. There were a range of methodologies, including four systematic reviews; UK studies were most common. The 28 papers were mapped to four broad areas of carer enquiry (some addressed more than one area): carer role ( $n=6$ [4-9]), role impact $(n=7$ [10$16])$, carer support ( $n=11$ [17-27]), and carer views $(n=4$ [28-31]).

[Table 1 about here, or appended]

\section{Carer role}

Bove et al's focus group study found spouses of patients with severe COPD experienced the carer role as undefined, with unpredictable responsibility [4•]. They were in a constant state of alertness due to fear of breathlessness, felt helpless and found it exhausting. Carers lived with modified social lives involving compromise, strategising, loss of contacts (including family), and managing reactions of others. They strove to maintain normality whilst trying to motivate the patient, taking on tasks 
and responsibilities with increasing concern about their future caring role. They experienced ambivalence about their relationship, struggling to preserve dignity whilst coping with patients' personality changes. They were willing carers but wanted support and knowledge for the role, and inclusion in decision-making with health care professionals (HCPs) [4•].

Aasb $\varnothing$ et al used qualitative interviews to explore how carers negotiate their role with patients and HCPs during acute COPD exacerbations [5•]. Carers lacked understanding and support from HCPs and were not always acknowledged as competent despite shouldering considerable responsibility. To avoid losing HCPs' cooperation carers strove to avoid being considered interfering or preventing HCPs from using their expertise, with implications for their own ability to maintain safety for the patient (in terms of managing their condition and the exacerbation) and control. There was again uncertainty in the carer role; the need to negotiate characterised its complexity, highlighting discrepancies between practice and policy regarding collaborative care [5•].

Hutchinson et al explored emergency department presentation of breathlessness using prospective patient survey methods and clinical record review [6•]. Most patients attending due to acute-onchronic breathlessness had non-malignant conditions. They identified key roles of family and friends: when asked who they talked to about their breathlessness it was usually their family doctor, but a quarter said family or friends. And when asked who was involved in the decision to attend the emergency department just over a third said themselves or family or friends, whereas the GP surgery or paramedic was involved in only about a fifth of decisions. Decisions on whether to present at the emergency department in acute-on-chronic breathlessness represents a significant burden for carers $[6 \bullet]$.

Bryant et al focused on the role of carers as co-workers in COPD: providing direct care, encouraging adherence to HCP recommendations, acting as health advocates, and providing emotional and psychosocial support [7]. Their systematic review examined how the carer role has been operationalised in interventions to improve outcomes for people with COPD. None of the nine 
included studies had intervention components directly targeted at carers: most included carers in HCP-delivered dyadic or group education sessions about COPD. Seven studies reported effective interventions (broad range of outcomes), with mixed risk of bias [7].

Figueiredo et al conducted qualitative interviews with male carers exploring experiences of husbands ( $n=7)$ and sons $(n=5)$ caring for family members with moderate to severe COPD [8]. Men were committed, dedicated carers; differences between husbands and sons reflected relational and generational differences relevant to intervention design. Differences related to the meaning of the commitment (for husbands an extension of the marital role, for sons a filial obligation), challenges and constraints (husbands struggled with household tasks and preserving their wives' integrity, sons struggled to conciliate their personal and professional lives with caring), fears and concerns about the future (husbands feared losing their life partner, sons feared inability to fulfil the role through illness), needs (husbands wanted practical skills, sons wanted information and self-confidence), and positive aspects (husbands gained from their wives' self-confidence and emotional strength, sons considered caring an opportunity for personal growth) [8].

Kayyali et al explored HCP perceptions of current COPD care pathways in five European countries [9]. Their findings predominantly related to service organisation and delivery but also reported the lack of a specified role for informal carers within those care pathways, and lack of professional support for that role [9].

\section{Impact of carer role}

Using survey methods, Badr et al examined individual-level predictors of patient and carer depression in COPD, and how dyad members effect each other's depression [10•]. Using PHQ9 thresholds, $20 \%$ of carers had mild and $8 \%$ moderate to severe depression. Multi-level models (dyads as unit of analysis) found higher levels of depression for both dyad members associated with 
less frequent patient self-management, higher carer burden, and being in poorer health. Women (patients or carers) were more likely to be depressed [10•].

Bernabeu-Mora et al also explored carer depression in COPD, but for patients hospitalised for acute exacerbations [11•]. Forty five of the 87 carers recruited reported depression at patient hospitalisation, with the strongest independent predictors of depression being spousal relationship, breathlessness, and severe airflow limitation. Depression resolved for $40 \%$ by 3-months postdischarge. Those caring $>20$ hours/week for patients with dependencies had decreased odds of remission; carers of patients with dependencies post-discharge had increased odds of becoming depressed $[11 \bullet]$.

Carers of hospitalised COPD patients were also investigated by Goris et al, but regarding care burden [12]. Their descriptive study of 112 carers (using validated tools) found higher levels of care burden for female carers, those who stated their physical and psychological health was affected, and those reporting difficulties giving care and needing help. Lower levels of social support were found for those with lower income, those whose physical and psychological health was affected, and, interestingly, for spouses [12].

Freeman et al examined associations between breathlessness and distress for both patients and carers receiving palliative home care as a unit of care, using data relating to 6,655 patients from an established database of service users [13]. Carers of patients with breathlessness were more likely to exhibit distress than those of patients not reporting breathlessness [13].

Tan et al explored interrelationships between carer burden, emotional status and quality of life among carers of patients with lung cancer participating in a feasibility randomised controlled trial (RCT) of a respiratory distress symptom cluster intervention [14•]. Analysis of data from 43 patientcarer dyads on validated scales found relationships between carer burden, quality of life and carer depression and anxiety. Carer depression and anxiety was also associated with patient depression 
and anxiety, suggesting that lung cancer patients and carers should be viewed as a unit in supportive service models [14•].

Impacts extend beyond physical and psychological. Dzingina et al's cross-sectional secondary analysis of data from a RCT of a palliative breathlessness support service enabled costing of informal (and formal) care [15••]. More than $75 \%$ of the 105 patients received care from family or friends. When cost of informal care was added to that of formal care, mean costs over a 3-month period rose by $>250 \%$ from $£ 3,253$ (standard deviation $£ 3,652$ ) to $f 11,507$ (standard deviation $£ 9,911$ ); informal care accounted for over $70 \%$ of costs. Over $64 \%$ of informal care cost related to the number of hours on call (45\%), providing help inside the home (9\%) and personal care (8\%). One factor associated with increased care costs was increased breathlessness $[15 \bullet \bullet]$.

Mansfield et al's systematic review of the volume and focus of research output relating to burden and unmet needs of carers of patients with COPD included 27 papers and identified a significant increase in publications [16]. Most were descriptive studies ( $n=25)$; only one measurement and one intervention study were found. Fourteen studies examined relationships between patient or carer factors and carer burden; only two measured carer burden over time. They identified a need for rigorous measurement tools to more accurately characterise carer burden to enable development of evidence-based interventions [16].

\section{Carer support and interventions}

The first step in carer support is identifying them [2] yet Sampson et al's retrospective cohort study of a UK primary care database of 13,693 bereaved cohabitees, which included carers of patients dying from cancer and lung disease (as well as dementia), concluded that recording of carers of terminally ill people was sub-optimal: only $6.9 \%$ of cohabitees were recorded as carers [17]. They also found the proportion of cohabitees with six or more consultations increased the year after bereavement (from $17.8 \%$ to $20.4 \%$ for COPD cohabitees) [17]. Systematic registration of every carer 
was one of several components of a Dutch COPD care programme tested by Cramm and Nieboer [18]: care delivery in accordance with the Chronic Care Model was associated with co-productive relationships (shared decision making) between professionals, COPD patients and their carers [18].

Farquhar et al reported on a mixed method RCT of a palliative care breathlessness intervention service for patients with non-malignant conditions (predominantly COPD) and their carers [19•]. Carers had anxiety and depression scores higher than population norms. Carers of patients receiving the intervention achieved greater (non-significant) reduction in their 'distress due to patient breathlessness' (numerical rating scale), and their anxiety, compared to controls. Qualitative analysis of carer (and patient) views identified positive service impacts both for patients and carers. Mechanisms of impact related to breathlessness acknowledgement and validation, and improved knowledge, which enhanced understanding and confidence for carers (and patients), reducing feelings of being alone with breathlessness. A potential therapeutic effect of trial-participation was identified for both patients and carers, additional to the intervention [19•].

Similar benefits of trial participation were found for carers by Ellis et al in their nested qualitative study to elicit views of patient and carer participants in a feasibility RCT of a respiratory distress symptom cluster intervention in lung cancer [20]. Carers reported greater understanding of symptoms through participation and appeared reassured by contact with the research team (which they regarded as a form of monitoring the patient's illness) [20]. Johnson et al sought views of carers (and patients) on the feasibility of an RCT to test the effect of a handheld fan on physical activity and carer anxiety in patients with refractory breathlessness but only one carer was recruited to this aspect of the study from the 12 patient recruits [21].

Figueiredo et al reported on a secondary analysis of the effects of a family-based pulmonary rehabilitation programme on close family carers of older patients with COPD [22•]. Quantitative data suggested the intervention maximised carers' adaptive coping, potentially preventing negative psychological outcomes through improved family coping, reframing, spiritual support seeking and 
mobilising to acquire help, reduced carer burden and physical demands of caring, improved reactions to caring and family support; qualitative data confirmed these benefits [22•].

Man et al sought to gain stakeholder consensus on key priorities for developing breathlessness rehabilitation services for patients with COPD and chronic heart failure: patient exercise training was considered a core component with other interventions, including the needs of carers [23].

Three papers related to the Learning about Breathlessness Study programme to develop an educational intervention for carers of patients with breathlessness in advanced disease [24-26]. Farquhar et al's systematic narrative review on educational interventions for carers found none focused on breathlessness [24•]. A follow-on qualitative study identified six topics carers of patients with breathlessness want to learn about (and why): 1) understanding breathlessness, 2) managing anxiety, panic and breathlessness, 3) managing infections, 4) keeping active, 5) living positively and 6) knowing what to expect in the future [25•]. And Ewing et al reported clinicians' views (online survey) of educational interventions for carers on breathlessness: predominant current practice was to educate carers by educating patients, and clinician advice on developing an intervention was patient-centric e.g. joint education with patients, giving carers practical advice and strategies for helping patients, and then measuring patient outcomes [26•]. Appetites for an intervention were strong in both clinicians [26•] and carers [25•].

Rosa et al's integrative review focused on the concept of resilience and family caring in COPD (12 papers) [27•]. Resilience was most often understood using a deficit, rather than an asset, model of health in COPD caring (focusing on problems rather than mobilising skills, knowledge and resources). They suggested carers need positive coping strategies to enable them to continue their caring role, and that better understanding of the concept of resilience may help nurses understand which supportive nursing interventions are more effective in helping carers [27•].

\section{Carer views}


Nakken et al's cross-sectional study of 188 patient-partner couples investigated differences between male and female partners of patients with COPD regarding their own characteristics and the perception of patients' characteristics: female partners thought male patients were less care dependent and had more symptoms of depression (no such sex-related differences were found in patients) [28].

Alami et al gathered relatives' (and patient and practitioner) views of pulmonary arterial hypertension (PAH), and potential improvements for medical care strategies, through qualitative interviews [29•]. There were divergent views of PAH and its impact. Relatives found PAH hard to understand; it disrupted relations with family and friends, and required them to adopt a caring role. They felt excluded from the care process (which focused on the patient), and lacked information on how to manage problems like fainting. They felt patients minimised aspects of the disease, such as breathlessness, and its impact on daily life [29•].

Collier et al's qualitative study of carers' perspectives on caring for someone on long-term oxygen therapy (LTOT) found that caring for someone with refractory breathlessness was extremely distressing [30•]. Carers felt benefits of LTOT were often overestimated and potential harms underestimated. Carers need opportunities to collaborate with clinicians in evidence-based decision making, and information and education about pharmacological and non-pharmacological strategies to manage refractory breathlessness, including LTOT [30•].

Schmidt et al compared perceptions of non-invasive ventilation (NIV) by intensive care unit (ICU) physicians ( $n=311)$, nurses ( $n=752)$, patients $(n=396)$ and their relatives $(n=145)$ in a prospective, multicentre ( $n=32$ ICUs) questionnaire study [31]. High NIV session-related anxiety was identified in $45 \%$ of relatives (and $37 \%$ of patients). They suggested that interventional studies are warranted given the close partnership required for NIV between a conscious patient and their (formal and informal) carers [31]. 


\section{CONCLUSION}

Recent evidence finds carers of patients with breathlessness taking on a role that is characterised by uncertainty, largely unsupported by HCPs. There is a lack of HCP acknowledgement of the contributions of, and impacts on, carers regarding breathlessness. HCPs should consider the patientcarer dyad as the unit of care. Carer intervention should be individualised, supporting carers both as clients and co-workers. There was a dearth of studies recruiting via primary care, focusing on conditions other than COPD, and longitudinal work.

\section{$\underline{\text { KEYPOINTS }}$}

1) Carers of patients with breathlessness take on a role that is characterised by uncertainty and unpredictability.

2) Carers are rarely acknowledged and largely unsupported by health care professionals: they should be supported both as clients and co-workers.

3) There was a lack of studies recruiting via primary care, focusing on conditions other than COPD, and longitudinal work.

\section{$\underline{\text { Acknowledgements }}$}

None.

Financial support and sponsorship

None.

\section{Conflicts of interest}


MF was an author on four of the 28 included papers.

\section{REFERENCES AND RECOMMENDED READING}

Papers of particular interest, published within the period of review (January 2016-May 2017), have been highlighted as:

- of special interest

$\bullet$ of outstanding interest

1. Hutchinson A. Patient and carer experience of breathlessness. In: Palliative Care in Respiratory Disease (ERS Monograph 73). Edited by Bausewein C, Currow DC and Johnson MJ (editors). Sheffield: European Respiratory Society;2-16. Chapter 7. ISBN (print): 978-1-84984-071-2.

2. Farquhar M. Supporting Informal Carers. In: Palliative Care in Respiratory Disease (ERS Monograph 73). Edited by Bausewein C, Currow DC and Johnson MJ (editors). Sheffield: European Respiratory Society;2-16. Chapter 4. ISBN (print): 978-1-84984-071-2.

3. Stajduhar KI, Nickel DD, Martin WL, Funk L. Situated/being situated: Client and co-worker roles of family caregivers in hospice palliative care. Soc Sci Med;2008;67(11):1789-1797.

4. Bove DG, Zakrisson AB, Midtgaard J et al. Undefined and unpredictable responsibility: a focus group study of the experiences of informal caregiver spouses of patients with severe COPD. J Clin Nurs;2016;25(3-4):483-493.

- Highlights the challenges of the caring role and lack of HCP support

5. Aasb $\varnothing$ G, Rugkåsa J, Solbraekke KN, Werner A. Negotiating the care-giving role: family members' 
experience during critical exacerbation of COPD in Norway. Health Soc Care Community 2017;25(2):612-620.

- Identifies discrepancy between policy and practice in relation to carer support

6. Hutchinson A, Pickering A, Williams P et al. Breathlessness and presentation to the emergency department: a survey and clinical record review. BMC Pulm Med;2017;20;17(1):53.

- Identifies role of family and friends in acute-on-chronic breathlessness

7. Bryant J, Mansfield E, Boyes AW et al. Involvement of informal caregivers in supporting patients with COPD: a review of intervention studies. Int J Chron Obstruct Pulmon Dis;2016;11:1587-1596.

8. Figueiredo D, Jácome C, Gabriel R, Marques A. Family care in chronic obstructive pulmonary disease: what happens when the carer is a man? Scand J Caring Sci;2016;30(4):721-730.

9. Kayyali R, Odeh B, Frerichs I et al. COPD care delivery pathways in five European Union countries: mapping and health care professionals' perceptions. Int J Chron Obstruct Pulmon Dis;2016;11:28312838.

10. Badr H, Federman AD, Wolf $M$ et al. Depression in individuals with chronic obstructive pulmonary disease and their informal caregivers. Aging Ment Health;2016;20:1-8.

- Identifies associations between patient and carer psychological morbidity

11. Bernabeu-Mora R, García-Guillamón G, Montilla-Herrador J et al. Rates and predictors of depression status among caregivers of patients with COPD hospitalized for acute exacerbations: a prospective study. Int J Chron Obstruct Pulmon Dis;2016;11:3199-3205.

- Identifies carer psychological morbidity for hospitalised patients 
12. Göriş S, Klç Z, Elmal F et al. Care burden and social support levels of caregivers of patients with chronic obstructive pulmonary disease. Holist Nurs Pract;2016;30(4):227-235.

13. Freeman S, Hirdes JP, Stolee P, Garcia J. A cross-sectional examination of the association between dyspnea and distress as experienced by palliative home care clients and their informal caregivers. Soc Work End Life Palliat Care;2016;12(1-2):82-103.

14. Tan JY, Molassiotis A, Lloyd-Williams M, Yorke J. Burden, emotional distress and quality of life among informal caregivers of lung cancer patients: an exploratory study. Eur J Cancer Care;2017 Apr 18. doi: 10.1111/ecc.12691. [Epub ahead of print]

- Highlights need for patient-carer dyads as the unit of care

15. Dzingina MD, Reilly CC, Bausewein C et al. Variations in the cost of formal and informal health care for patients with advanced chronic disease and refractory breathlessness: A cross-sectional secondary analysis. Palliat Med;2017;31(4):369-377.

-. Identifies the considerable financial value of the informal caring role

16. Mansfield E, Bryant J, Regan T et al. Burden and unmet needs of caregivers of chronic obstructive pulmonary disease patients: a systematic review of the volume and focus of research output. COPD;2016;13(5):662-667.

17. Sampson EL, Lodwick R, Rait $\mathrm{G}$ et al. Living with an older person dying from cancer, lung disease, or dementia: health outcomes from a general practice cohort study. J Pain Symptom Manage;2016;51(5):839-848. 
18. Cramm JM, Nieboer AP. The changing nature of chronic care and coproduction of care between primary care professionals and patients with COPD and their informal caregivers. Int J Chron Obstruct Pulmon Dis;2016;11:175-182.

19. Farquhar M, Prevost AT, McCrone P et al. The clinical and cost-effectiveness of a Breathlessness Intervention Service for patients with advanced non-malignant disease and their informal carers mixed findings of a mixed method randomised controlled trial. BMC Trials;2016;17:185.

- Identifies impact on carers of a palliative care intervention for intractable breathlessness

20. Ellis J, Warden J, Molassiotis A et al. Participation in a randomised controlled feasibility study of a complex intervention for the management of the Respiratory Symptom Distress Cluster in lung cancer: patient, carer and research staff views. Eur J Cancer Care;2016 Jul 8. doi: 10.1111/ecc.12538. [Epub ahead of print]

21. Johnson MJ, Booth S, Currow DC et al. A mixed-methods, randomized, controlled feasibility trial to inform the design of a Phase III trial to test the effect of the handheld fan on physical activity and carer anxiety in patients with refractory breathlessness. J Pain Symptom Manage;2016;51(5):807815.

22. Figueiredo D, Cruz J, Jácome C, Marques A. Exploring the benefits to caregivers of a familyoriented pulmonary rehabilitation program. Respir Care;2016;61(8):1081-1089.

- Reports on outcomes of a family-based intervention

23. Man WD, Chowdhury F, Taylor RS et al. Building consensus for provision of breathlessness rehabilitation for patients with chronic obstructive pulmonary disease and chronic heart failure. Chron Respir Dis;2016;13(3):229-239. 
24. Farquhar M, Penfold C, Walter F et al. What are the key elements of educational interventions for lay carers of patients with advanced disease? A systematic literature search and narrative review of structural components, processes and modes of delivery. J Pain Symptom Manage;2016;52(1):117-130.

- Identifies absence of educational interventions for carers on breathlessness

25. Farquhar M, Penfold C, Benson J et al. Six key topics informal carers of patients with breathlessness in advanced disease want to learn about and why: MRC Phase I study to inform an educational intervention. PLoS ONE;2017;12(5):e0177081.

- Identifies carer desire for an educational intervention for carers on breathlessness and topics carers want to learn about

26. Ewing G, Penfold C, Benson J et al. Clinicians' views of educational interventions for carers of patients with breathlessness due to advanced disease: findings from an online survey. J Pain Symptom Manage;2017;55(2):265-271.

- Identifies clinician appetite for an educational intervention for carers on breathlessness and suggests possible modes of delivery

27. Rosa F, Bagnasco A, Aleo $G$ et al. Resilience as a concept for understanding family caregiving of adults with Chronic Obstructive Pulmonary Disease (COPD): an integrative review. Nurs Open;2016; $11 ; 4(2): 61-75$.

- Explores the concept of resilience and its potential inclusion in interventions

28. Nakken N, Janssen DJ, van Vliet M et al. Gender differences in partners of patients with COPD and their perceptions about the patients. Int J Chron Obstruct Pulmon Dis;2016;12:95-104. 
29. Alami S, Cottin V, Mouthon L et al. Patients', relatives', and practitioners' views of pulmonary arterial hypertension: a qualitative study. Presse Med;2016;45(2):e11-27.

- Identifies divergent views on PAH which may inform intervention design

30. Collier A, Breaden K, Phillips JL et al. Caregivers' perspectives on the use of long-term oxygen therapy for the treatment of refractory breathlessness: a qualitative study. J Pain Symptom Manage;2017;53(1):33-39.

- Identifies carers' views of LTOT and carer need in relation to LTOT

31. Schmidt M, Boutmy-Deslandes E, Perbet S et al. Differential perceptions of noninvasive ventilation in intensive care among medical caregivers, patients, and their relatives: a multicenter prospective study - the PARVENIR Study. Anesthesiology. 2016;124(6):1347-1359. 


\begin{tabular}{|c|c|c|c|}
\hline Dates: & \multicolumn{3}{|c|}{ January 2016 and May 2017 (16/05/2017) } \\
\hline Databases: & \multicolumn{3}{|c|}{ Medline, CINAHL, Scopus, PsychInfo, PubMed } \\
\hline $\begin{array}{l}\text { Search } \\
\text { terms: }\end{array}$ & $\begin{array}{l}\text { Carers/caregivers/family } \\
\text { members/relatives/informal } \\
\text { carers }\end{array}$ & AND & $\begin{array}{l}\text { Breathlessness/dyspnea/dyspnoea/ } \\
\text { shortness of breath }\end{array}$ \\
\hline $\begin{array}{l}\text { Inclusion } \\
\text { criteria: }\end{array}$ & \multicolumn{3}{|c|}{$\begin{array}{l}\text { - Findings relate to carers and breathlessness } \\
\text { - Empirical study or systematic review only } \\
\text { - Peer-reviewed } \\
\text { - Written in English }\end{array}$} \\
\hline
\end{tabular}




\begin{tabular}{|c|c|c|c|c|c|}
\hline $\begin{array}{l}\text { Broad area } \\
\text { of enquiry } \\
\text { regarding } \\
\text { carers }\end{array}$ & \begin{tabular}{|l} 
First author, \\
year (country)
\end{tabular} & Carer recruitment & Carer characteristics & Patient diagnosis/group & Methodology \\
\hline Carer role & $\begin{array}{l}\text { Bove et al, } \\
2016[4 \bullet] \\
\text { (Denmark) }\end{array}$ & $\begin{array}{l}\text { Via patients attending } \\
\text { secondary care } \\
\text { pulmonary } \\
\text { department }\end{array}$ & $\begin{array}{l}22 \text { carers } \\
11 \text { women, } 9 \text { men } \\
\text { Mean age: } 69.4 y r s(61-82 y r s) \\
21 \text { cohabited }>20 y r s\end{array}$ & $\begin{array}{l}\text { Severe COPD } \\
\text { (GOLD stages C \& D) }\end{array}$ & $\begin{array}{l}\text { Qualitative: } \\
\text { Focus groups with carers } \\
(n=3)\end{array}$ \\
\hline Carer role & $\begin{array}{l}\text { Aasb } \varnothing \text { et al, } \\
2016[5 \bullet] \\
\text { (Norway) }\end{array}$ & $\begin{array}{l}\text { Via nurses from } \\
\text { ambulatory secondary } \\
\text { care pulmonary } \\
\text { services }\end{array}$ & $\begin{array}{l}10 \text { spousal carers } \\
6 \text { women, } 4 \text { men } \\
\text { Aged } 61-84 \mathrm{yrs} \text { ( } 7>70 \mathrm{yrs})\end{array}$ & Severe or very severe COPD & $\begin{array}{l}\text { Qualitative: } \\
\text { Semi-structured interviews } \\
\text { with carers }\end{array}$ \\
\hline Carer role & $\begin{array}{l}\text { Hutchinson et } \\
\text { al, } 2017[6 \bullet] \\
\text { (UK) }\end{array}$ & $\mathrm{N} / \mathrm{A}$ & N/A & $\begin{array}{l}\text { Patients attending } \\
\text { emergency department with }\end{array}$ & Quantitative: \\
\hline
\end{tabular}




\begin{tabular}{|c|c|c|c|c|c|}
\hline & & & & $\begin{array}{l}\text { acute-on-chronic } \\
\text { breathlessness }\end{array}$ & $\begin{array}{l}\text { Clinician administered } \\
\text { patient-report survey } \\
\text { Clinical record review }\end{array}$ \\
\hline Carer role & $\begin{array}{l}\text { Bryant et al, } \\
2016 \text { [7] } \\
\text { (n/a systematic } \\
\text { review) }\end{array}$ & $\begin{array}{l}\text { Various } \\
\text { (systematic review) }\end{array}$ & $\begin{array}{l}\text { Various } \\
\text { (systematic review) }\end{array}$ & COPD & Systematic review \\
\hline Carer role & $\begin{array}{l}\text { Figueiredo et al, } \\
2016 \text { [8] } \\
\text { (Portugal) }\end{array}$ & $\begin{array}{l}\text { Via clinicians of } \\
\text { patients attending } \\
\text { secondary care } \\
\text { outpatients }\end{array}$ & $\begin{array}{l}12 \text { carers } \\
\text { All male } \\
7 \text { husbands: mean age } 70.9 y r s \\
\text { ( } \mathrm{SD}=8.8) \\
5 \text { sons: mean age } 43.4 \mathrm{yrs} \\
\text { ( } \mathrm{SD}=10.5)\end{array}$ & Moderate to severe COPD & $\begin{array}{l}\text { Qualitative: } \\
\text { In-depth semi-structured } \\
\text { interviews with carers }\end{array}$ \\
\hline Carer role & $\begin{array}{l}\text { Kayyali et al, } \\
2016 \text { [9] }\end{array}$ & N/A & N/A & COPD & $\begin{array}{l}\text { Qualitative: } \\
\text { Semi-structured interviews } \\
\text { (face to face and email) }\end{array}$ \\
\hline
\end{tabular}




\begin{tabular}{|c|c|c|c|c|c|}
\hline & $\begin{array}{l}\text { (Five European } \\
\text { countries: } \\
\text { England, } \\
\text { Ireland, the } \\
\text { Netherlands, } \\
\text { Greece, and } \\
\text { Germany) }\end{array}$ & & & & $\begin{array}{l}\text { with health care } \\
\text { professionals }\end{array}$ \\
\hline Carer impact & $\begin{array}{l}\text { Badr et al, } 2016 \\
{[10 \bullet]} \\
\text { (USA) }\end{array}$ & $\begin{array}{l}\text { Via patient } \\
\text { participants who were } \\
\text { attending secondary } \\
\text { care outpatient clinics }\end{array}$ & $\begin{array}{l}89 \text { carers } \\
\text { Mean age } 54.8 y r s(S D=16.0) \\
68 \text { women }(76 \%), 21 \text { men } \\
\text { In carer role for }>6 \text { months }\end{array}$ & COPD & $\begin{array}{l}\text { Quantitative: } \\
\text { Structured interviews with } \\
89 \text { patient-carer dyads } \\
\text { (data collected separately) }\end{array}$ \\
\hline Carer impact & $\begin{array}{l}\text { Bernabeu-Mora } \\
\text { et al, } 2016 \text { [11•] } \\
\text { (Spain) }\end{array}$ & $\begin{array}{l}\text { Via patients admitted } \\
\text { to secondary care } \\
\text { pulmonary service }\end{array}$ & $\begin{array}{l}87 \text { carers } \\
\text { Depressed carers: mean age } \\
62.9 \mathrm{yrs}(\mathrm{SD}=13.49 \mathrm{~s}) ; 43 \\
\text { women }(96 \%), 2 \text { men }\end{array}$ & COPD (hospitalised) & $\begin{array}{l}\text { Quantitative: } \\
\text { Structured face to face } \\
\text { interviews with carers } \\
\text { during admission }\end{array}$ \\
\hline
\end{tabular}




\begin{tabular}{|c|c|c|c|c|c|}
\hline & & & $\begin{array}{l}\text { Non-depressed carers: mean } \\
\text { age } 61.79 \text { yrs (SD=12.82); } 35 \\
\text { women }(83 \%), 7 \text { men }\end{array}$ & & $\begin{array}{l}\text { Structured phone } \\
\text { interviews with carers 3- } \\
\text { months post-discharge }\end{array}$ \\
\hline Carer impact & $\begin{array}{l}\text { Goris et al, } 2016 \\
\text { [12] } \\
\text { (Turkey) }\end{array}$ & $\begin{array}{l}\text { Via patients admitted } \\
\text { to secondary care } \\
\text { chest diseases service }\end{array}$ & $\begin{array}{l}112 \text { carers } \\
\text { Age groups: } \\
\leq 39 y r s n=32(28.6 \%) \\
40-49 y r s n=24(21.4 \%) \\
50-59 y r s n=26(23.2 \%) \\
\geq 60 y r s n=30(26.8 \%) \\
84 \text { women }(75 \%), 28 \text { men }\end{array}$ & COPD (hospitalised) & $\begin{array}{l}\text { Quantitative: } \\
\text { Structured face to face } \\
\text { interviews with carers } \\
\text { during admission }\end{array}$ \\
\hline Carer impact & $\begin{array}{l}\text { Freeman et al, } \\
2016[13] \\
\text { (Canada) }\end{array}$ & $\begin{array}{l}\text { Sample drawn from } \\
\text { anonymised interRAI } \\
\text { Palliative Care } \\
\text { Assessment data } \\
\text { gathered on } 6,655 \\
\text { palliative home care }\end{array}$ & $\begin{array}{l}6,530 \text { carers } \\
\text { No age/sex data } \\
\text { Primary carer relationship to } \\
\text { client: } \\
\text { Child } 29.1 \%(1,897) \\
\text { Spouse/Partner } 58.6 \%(3,823)\end{array}$ & $\begin{array}{l}\text { Various: } \\
\text { Cancer only } 59.7 \%(3,973) \\
\text { Non-cancer only 9.8\% (649) } \\
\text { Both cancer + non-cancer } \\
27.2 \%(1,812) \\
\text { Unspecified } 3.3 \%(221)\end{array}$ & $\begin{array}{l}\text { Quantitative: } \\
\text { Cross-sectional analysis of } \\
\text { data collected by trained } \\
\text { assessors (e.g. nurses, } \\
\text { social workers, case } \\
\text { managers) using }\end{array}$ \\
\hline
\end{tabular}




\begin{tabular}{|c|c|c|c|c|c|}
\hline & & $\begin{array}{l}\text { clients as part of a } \\
\text { pilot implementation }\end{array}$ & $\begin{array}{l}\text { Other } 12.4 \%(810) \\
\text { No carer } 1.9 \%(125)\end{array}$ & & $\begin{array}{l}\text { information from } \\
\text { observation and discussion } \\
\text { with the client }\end{array}$ \\
\hline Carer impact & $\begin{array}{l}\text { Tan et al, } 2017 \\
{[14 \bullet]} \\
\text { (UK) }\end{array}$ & $\begin{array}{l}\text { Via patients } \\
\text { participating in a } \\
\text { feasibility RCT of a } \\
\text { respiratory distress } \\
\text { symptom cluster } \\
\text { intervention }\end{array}$ & $\begin{array}{l}43 \text { carers } \\
\text { Age groups: } \\
<70 y r s n=28(65.1 \%) \\
\geq 70 y r s n=12(27.9 \%) \\
\text { Mean age } 61.7 y r s(S D=12.4) \\
28 \text { women }(65 \%), 15 \text { men }\end{array}$ & $\begin{array}{l}\text { Lung cancer } \\
\text { (participating in a feasibility } \\
\text { RCT of a respiratory distress } \\
\text { symptom cluster } \\
\text { intervention) }\end{array}$ & $\begin{array}{l}\text { Quantitative: } \\
\text { Cross-sectional secondary } \\
\text { analysis of self-completed } \\
\text { questionnaires from RCT }\end{array}$ \\
\hline Carer impact & $\begin{array}{l}\text { Dzingina et al, } \\
2017[15 \bullet \bullet] \\
\text { (UK) }\end{array}$ & N/A & N/A & $\begin{array}{l}\text { Advanced disease (e.g. } \\
\text { cancer, COPD, chronic heart } \\
\text { failure, interstitial lung } \\
\text { disease and motor neuron } \\
\text { disease) and refractory } \\
\text { breathlessness on exertion/ } \\
\text { rest optimum treatment of }\end{array}$ & $\begin{array}{l}\text { Quantitative: } \\
\text { Cross-sectional secondary } \\
\text { analysis of data } \\
\text { from RCT } \\
\text { Structured patient } \\
\text { interviews }\end{array}$ \\
\hline
\end{tabular}




\begin{tabular}{|c|c|c|c|c|c|}
\hline & & & & $\begin{array}{l}\text { underlying disease } \\
\text { (participating in a RCT of a } \\
\text { palliative breathlessness } \\
\text { support service) }\end{array}$ & \\
\hline Carer impact & $\begin{array}{l}\text { Mansfield et al, } \\
2016[16] \\
\text { (n/a systematic } \\
\text { review) }\end{array}$ & $\begin{array}{l}\text { Various } \\
\text { (systematic review) }\end{array}$ & $\begin{array}{l}\text { Various } \\
\text { (systematic review) }\end{array}$ & COPD & Systematic review \\
\hline $\begin{array}{l}\text { Carer } \\
\text { support }\end{array}$ & $\begin{array}{l}\text { Sampson et al, } \\
2016 \text { [17] } \\
\text { (UK) }\end{array}$ & $\begin{array}{l}\text { Used The Health } \\
\text { Improvement Network } \\
\text { (THIN: database of } \\
\text { over } 500 \text { primary care } \\
\text { practices) to identify } \\
\text { cohabitees of patients } \\
\text { who had died of } \\
\text { cancer, dementia or }\end{array}$ & $\begin{array}{l}\text { 13,693 cohabitees } \\
\text { COPD cohabitees ( } n=6041) \text { : } \\
\text { Median age 77yrs (IQR 71-82) } \\
\text { Women } 71 \%(4,304)\end{array}$ & Cancer, dementia or COPD & $\begin{array}{l}\text { Quantitative: } \\
\text { Retrospective cohort study } \\
\text { using THIN }\end{array}$ \\
\hline
\end{tabular}




\begin{tabular}{|c|c|c|c|c|c|}
\hline & & $\begin{array}{l}\text { COPD, as proxy for } \\
\text { carers }\end{array}$ & & & \\
\hline $\begin{array}{l}\text { Carer } \\
\text { support }\end{array}$ & $\begin{array}{l}\text { Cramm et al, } \\
2016[18] \\
\text { (Netherlands) }\end{array}$ & N/A & $\mathrm{N} / \mathrm{A}$ & COPD & $\begin{array}{l}\text { Quantitative: } \\
\text { Cross-sectional study of } \\
\text { 411/981 patients enrolled } \\
\text { in the Dutch COPD care } \\
\text { program Kennemer Lucht } \\
\text { and } 62 / 97 \text { HCPs }\end{array}$ \\
\hline $\begin{array}{l}\text { Carer } \\
\text { support }\end{array}$ & $\begin{array}{l}\text { Farquhar et al, } \\
2016[19 \bullet] \\
\text { (UK) }\end{array}$ & $\begin{array}{l}\text { Via patients } \\
\text { participating in RCT of } \\
\text { a palliative } \\
\text { Breathlessness } \\
\text { Intervention Service }\end{array}$ & $\begin{array}{l}57 \text { carers } \\
\text { Mean age } 62.2 y r s(S D=13.39) \\
\text { Women } 79 \%(n=45)\end{array}$ & $\begin{array}{l}\text { Advanced non-malignant } \\
\text { disease (83\% COPD) } \\
\text { (participating in a RCT of a } \\
\text { palliative Breathlessness } \\
\text { Intervention Service) }\end{array}$ & $\begin{array}{l}\text { Mixed method RCT: } \\
\text { quantitative outcome } \\
\text { measures and topic-guided } \\
\text { interviews with all } \\
\text { participants }\end{array}$ \\
\hline $\begin{array}{l}\text { Carer } \\
\text { support }\end{array}$ & $\begin{array}{l}\text { Ellis et al, } 2016 \\
{[20]}\end{array}$ & $\begin{array}{l}\text { Via patients } \\
\text { participating in a }\end{array}$ & $\begin{array}{l}\text { Purposive sample } \\
\text { Three carers }\end{array}$ & Lung cancer & Qualitative: \\
\hline
\end{tabular}




\begin{tabular}{|c|c|c|c|c|c|}
\hline & (UK) & $\begin{array}{l}\text { feasibility RCT of a } \\
\text { respiratory distress } \\
\text { symptom cluster } \\
\text { intervention }\end{array}$ & $\begin{array}{l}\text { Two women, one man } \\
\text { No age data }\end{array}$ & $\begin{array}{l}\text { (participating in a feasibility } \\
\text { RCT of a respiratory distress } \\
\text { symptom cluster } \\
\text { intervention) }\end{array}$ & $\begin{array}{l}\text { nested qualitative study } \\
\text { within a mixed method } \\
\text { feasibility RCT }\end{array}$ \\
\hline $\begin{array}{l}\text { Carer } \\
\text { support }\end{array}$ & $\begin{array}{l}\text { Johnson et al, } \\
2016[21] \\
\text { (UK) }\end{array}$ & $\begin{array}{l}\text { Via patients } \\
\text { participating in a } \\
\text { feasibility RCT of a } \\
\text { handheld fan for } \\
\text { refractory } \\
\text { breathlessness }\end{array}$ & $\begin{array}{l}\text { Only one carer (and } 12 \\
\text { patients) recruited to the } \\
\text { qualitative aspect of the study }\end{array}$ & $\begin{array}{l}\text { Feasibility RCT sample's } \\
\text { primary disease } \\
\text { (intervention/control } \\
\text { groups): } \\
\text { COPD n=12 (50\%) /n=11 } \\
(46 \%) \\
\text { Cancer/ heart diseases } n=6 \\
(25 \%) / n=7(29 \%) \\
\text { Others } n=6(25 \%) / n=6(25 \%)\end{array}$ & $\begin{array}{l}\text { Qualitative: } \\
\text { nested qualitative study } \\
\text { within a mixed method } \\
\text { feasibility RCT }\end{array}$ \\
\hline $\begin{array}{l}\text { Carer } \\
\text { support }\end{array}$ & $\begin{array}{l}\text { Figueiredo et al, } \\
2016[22 \bullet]\end{array}$ & Family & $\begin{array}{l}56 \text { family carers } \\
\text { Mean age: } 59 y r s(S D=11.2)\end{array}$ & COPD & $\begin{array}{l}\text { Secondary analysis of } \\
\text { mixed method RCT data }\end{array}$ \\
\hline
\end{tabular}




\begin{tabular}{|c|c|c|c|c|c|}
\hline & (Portugal) & $\begin{array}{l}\text { dyads (i.e. subjects } \\
\text { with COPD and family } \\
\text { carers) recruited to an } \\
\text { RCT of a Family- } \\
\text { Oriented Pulmonary } \\
\text { Rehabilitation } \\
\text { Program }\end{array}$ & Women 74\% $(n=29)$ & & \\
\hline $\begin{array}{l}\text { Carer } \\
\text { support }\end{array}$ & $\begin{array}{l}\text { Man et al, } 2016 \\
\text { [23] } \\
\text { (UK) }\end{array}$ & N/A & N/A & $\begin{array}{l}\text { N/A (no patients recruited, } \\
\text { but target population for } \\
\text { intervention COPD and } \\
\text { chronic heart failure) }\end{array}$ & $\begin{array}{l}\text { Stakeholder consensus } \\
\text { methods }\end{array}$ \\
\hline $\begin{array}{l}\text { Carer } \\
\text { support }\end{array}$ & $\begin{array}{l}\text { Farquhar et al, } \\
2016[24 \bullet] \\
\text { (n/a systematic } \\
\text { review) }\end{array}$ & $\begin{array}{l}\text { Various } \\
\text { (systematic review) }\end{array}$ & $\begin{array}{l}\text { Various } \\
\text { (systematic review) }\end{array}$ & $\begin{array}{l}\text { Advanced disease - various } \\
\text { (systematic review) }\end{array}$ & $\begin{array}{l}\text { Systematic narrative } \\
\text { review }\end{array}$ \\
\hline
\end{tabular}




\begin{tabular}{|c|c|c|c|c|c|}
\hline $\begin{array}{l}\text { Carer } \\
\text { support }\end{array}$ & $\begin{array}{l}\text { Farquhar et al, } \\
2017 \text { [25•] } \\
\text { (UK) }\end{array}$ & $\begin{array}{l}\text { Via patients in primary } \\
\text { care and secondary } \\
\text { care oncology or } \\
\text { respiratory medicine } \\
\text { departments }\end{array}$ & $\begin{array}{l}25 \text { carers } \\
\text { Mean age 68yrs (42-84) } \\
21 \text { women, } 4 \text { men }\end{array}$ & $\begin{array}{l}\text { Cancer ( } n=13 \text { ) or COPD } \\
\text { ( } n=12) \text { and troubled by } \\
\text { breathlessness and } \\
\text { intractable breathlessness in } \\
\text { spite of optimisation of } \\
\text { underlying illness }\end{array}$ & $\begin{array}{l}\text { Qualitative: } \\
\text { Topic guided interviews } \\
\text { with carers (and patients) }\end{array}$ \\
\hline $\begin{array}{l}\text { Carer } \\
\text { support }\end{array}$ & $\begin{array}{l}\text { Ewing et al, } \\
2016[26 \bullet] \\
\text { (UK) }\end{array}$ & N/A & N/A & $\begin{array}{l}\text { N/A (no patients recruited, } \\
\text { but target population for } \\
\text { intervention are carers of } \\
\text { patients with breathlessness } \\
\text { due to advanced disease) }\end{array}$ & $\begin{array}{l}\text { Mixed methods: } \\
\text { Online survey of } 365 \\
\text { clinicians including fixed } \\
\text { choice answers and free } \\
\text { text responses }\end{array}$ \\
\hline $\begin{array}{l}\text { Carer } \\
\text { support }\end{array}$ & $\begin{array}{l}\text { Rosa et al, } 2017 \\
{[27 \bullet]} \\
\text { (n/a systematic } \\
\text { review) }\end{array}$ & $\begin{array}{l}\text { Various } \\
\text { (systematic review) }\end{array}$ & $\begin{array}{l}\text { Various } \\
\text { (systematic review) }\end{array}$ & COPD & Systematic review \\
\hline
\end{tabular}




\begin{tabular}{|c|c|c|c|c|c|}
\hline Carer views & $\begin{array}{l}\text { Nakken et al, } \\
2017 \text { [28] } \\
\text { (Netherlands) }\end{array}$ & $\begin{array}{l}\text { Via patient } \\
\text { participants who were } \\
\text { attending secondary } \\
\text { care respiratory clinics }\end{array}$ & $\begin{array}{l}188 \text { partners } \\
\text { Female partners }(n=103) \text { : } \\
\text { mean ae } 65.4 y r s(S D=8.6) \\
\text { Male partners }(n=85) \text { : mean } \\
\text { age } 65.1 y r s(S D=8.9)\end{array}$ & $\begin{array}{l}\text { Moderate to very severe } \\
\text { COPD (GOLD II, III or IV) }\end{array}$ & $\begin{array}{l}\text { Quantitative: } \\
\text { Home visits collected data } \\
\text { from } 188 \text { patient-partner } \\
\text { couples using a range of } \\
\text { questionnaires }\end{array}$ \\
\hline Carer views & $\begin{array}{l}\text { Alami et al, } \\
2016[29 \bullet] \\
\text { (France) }\end{array}$ & $\begin{array}{l}\text { Via patient } \\
\text { participants who were } \\
\text { attending secondary } \\
\text { care Pulmonary } \\
\text { Arterial Hypertension } \\
\text { clinics }\end{array}$ & $\begin{array}{l}4 \text { relatives } \\
2 \text { women, } 2 \text { men } \\
\text { Age range: } 35-59 y r s\end{array}$ & $\begin{array}{l}\text { Pulmonary Arterial } \\
\text { Hypertension }\end{array}$ & $\begin{array}{l}\text { Qualitative: } \\
\text { Semi-structured interviews } \\
\text { with } 16 \text { patients, } 4 \text { relatives } \\
\text { and } 9 \text { practitioners }\end{array}$ \\
\hline Carer views & $\begin{array}{l}\text { Collier et al, } \\
2017[30 \bullet] \\
\text { (Australia) }\end{array}$ & $\begin{array}{l}\text { Self-nomimated carers } \\
\text { of people using long- } \\
\text { term oxygen therapy } \\
\text { (LTOT) via specialist } \\
\text { palliative care services }\end{array}$ & $\begin{array}{l}20 \text { carers } \\
13 \text { women, } 7 \text { men } \\
\text { No age data } \\
\text { Spouses ( } n=14) \text {, friends }(n=1) \text {, } \\
\text { adult children }(n=5)\end{array}$ & $\begin{array}{l}\text { People using LTOT for } \\
\text { refractory breathlessness }\end{array}$ & $\begin{array}{l}\text { Qualitative: } \\
\text { Semi-structured interviews } \\
\text { with carers }\end{array}$ \\
\hline
\end{tabular}




\begin{tabular}{|c|c|c|c|c|c|}
\hline Carer views & $\begin{array}{l}\text { Schmidt et al, } \\
2016[31] \\
\text { (France) }\end{array}$ & $\begin{array}{l}\text { Patients and relatives } \\
\text { screened for inclusion } \\
\text { on discharge from } \\
\text { Intensive Care Unit } \\
\text { (ICU) }\end{array}$ & $\begin{array}{l}145 \text { relatives (e.g. family } \\
\text { member, partner, or close } \\
\text { friend) who had visited } \\
\text { relative at least once during a } \\
\text { non-invasive ventilation (NIV) } \\
\text { session } \\
\text { Median age 59yrs (IQR 47-69) } \\
\text { Men 38\% (n=54) }\end{array}$ & $\begin{array}{l}\text { Patients who had received } \\
\text { NIV for more than } 4 \text { hours } \\
\text { during their ICU stay, and } \\
\text { had not been intubated } \\
\text { before or after NIV }\end{array}$ & $\begin{array}{l}\text { Quantitative: } \\
\text { Prospective multi-centre } \\
\text { questionnaire-based study } \\
\text { involving } 311 \text { ICU } \\
\text { physicians, } 752 \text { nurses, } 396 \\
\text { patients, and } 145 \text { relatives } \\
\text { from } 32 \text { ICUs }\end{array}$ \\
\hline
\end{tabular}


